\title{
Problems and Countermeasures of Rural Collective Land Capitalization in Wenjiang District
}

\author{
Wei Sun ${ }^{1, a}$, Yumei Chen, ${ }^{2, b}$ \\ ${ }^{1}$ School of Management, Sichuan Agricultural University, Chengdu, Sichuan, P.R. China \\ ${ }^{2}$ School of Economics, Sichuan Agricultural University, Chengdu, Sichuan, P.R. China \\ a598112170@qq.com, bmei.sicau@outlook.com
}

Keywords: Rural Areas, Land Reform, Capitalization of Land.

\begin{abstract}
With the reform of rural collective land, the promotion of the construction of new socialist countryside, the rapid development of urbanization and the capitalization of land are the inevitable choices of rural economic development. We find that land capitalization encounter a lot of problems while bringing tangible benefits to the society. Through the analysis of the capitalization of rural collective land in Wenjiang district of Chengdu, the problems are found and the corresponding countermeasures are consequently put forward.
\end{abstract}

\section{Introduction}

In 2017, "No.1 Document of Central Government"took the"three rural issues" as the main theme, and the document clearly proposed the reform of rural collective property rights system, effectively protectingthe rights of the peasants, including land contract management right and income distribution right. With the gradual deepening of rural reform and the rapid development of urbanization, traditional land pattern can not meet the needs of modern agriculture development, and the defects of the existing land institution design are becoming obvious. Thus, the capitalization of rural land has become an inevitable choice of rural economic development.

Through the capitalization of collective land resources, the countryside can introduce foreign capital and city capital, attract people with technology and knowledge into rural areas, solve the problems of capital and technology, realize agricultural scale management, improve labor productivity, and realize agricultural industrialization and modernization. This not only accelerates the transformation of land-use rights and fully and effectively utilizes rural collective land resources, but also increases farmers' income and promotes the development of modern agriculture. In addition, based on the discussion of the problems of rural collective land capitalization, this paper puts forward countermeasures to provide demonstration experience for the implementation of rural land capitalization in other regions of China.

\section{General Situation of Wenjiang District}

The implementation of the collective land reform in Wenjiang district of Chengdu is based on the requirement for adapting and promoting the development of rural productive forces and farmers' sustainable income, based on the improvement of the rural grass-roots management structure and the social stability, which breaks through the long-term segmentation of the urban-rural economy and accelerates the circulation of agricultural production. Scientific reform of land rights speeds up the extension of land resources, which bring great practical significance to carry out intensive production and market operation, to improve the income of farmers and even rural economic organizations. 
In 2008, the rural property exchange of Wenjiang District was established to provide services for the transfer of rural property rights and the investment, especially the financing of agricultural industrialization projects for forest, land contract and management rights, rural housing property rights, collective construction land use rights, rural economic organizations, etc., which promoted the rational flow of rural property rights. By the end of 2016, 87 villages(communities), 984 groups had completed the rights certification work, and the government had issued a contract of management license st 65,400 and 191,700 acres. The following table is the land circulation situation of Wenjiang District.From 2010 to 2015, a total of 1375.81 acres of land have been traded,with the turnover reaching 48717.94 million yuan.

Table 1 Land circulation in Wenjiang District

\begin{tabular}{|c|c|c|c|}
\hline Year & Volume[acre] & Number & Turnover[Million yuan] \\
\hline 2010 & 337.77 & 9 & 6161.51 \\
\hline 2011 & 308.28 & 11 & 11823.46 \\
\hline 2012 & 139.92 & 9 & 4869.69 \\
\hline 2013 & 310.56 & 20 & 12963.02 \\
\hline 2014 & 217.39 & 14 & 8073.07 \\
\hline 2015 & 61.89 & 6 & 4827.19 \\
\hline Total & 1375.81 & 69 & 48717.94 \\
\hline
\end{tabular}

Data Source: Wenjiang District of Chengdu Rural Property Exchange

\section{Theoretical Analysis}

Capitalization is the process of exchanging exchange value in the current market where assets are converted into other assets by virtue of their proceeds. In Marx's view, land rights were capitalized when land had the right to bring benefits into the market and free trade. Land capitalization is actually the capitalization of land rent, in essence, the capitalization of ownership. The theory of property right is determined by the bourgeois world outlook and methodology, and it reflects the demand of asset interests in general. The theory of sustainable development refers to the development of the ability to meet the needs of contemporary people and not to harm the ability to meet the needs of future generations[1]. The foundation of the theory of sustainable utilization of resources is that the sustainability of human society depends on whether the natural resources on which human beings live can be used indefinitely. Land is a kind of non-renewable natural economic element. So when considering the requirement of economic development to market allocation of land resources, we should not only try our best to make the allocation of land resources to exert the optimum economic effect, but also discuss the existing problems and influencing factors on this basis.

\section{Problems in the Capitalization of Rural Collective Land in Wenjiang District}

Use and Circulation of Land. There are still many problems in the process of land use and circulation, including the organizational form of the existing cooperative organization, the defective design and implementation of the land use rules and regulations, the current land system's inconsistent definition of property right, the nonstandard and insufficient feasibility of land use right circulation. The form of the current cooperative organization in Wenjiang District 
is the farmer cooperative organization, which is not sufficiently normative, and the mechanism of democratic election and equal decision-making are not perfect.

Distribution of Proceeds. Including inequitable income distribution and inadequate implementation, the opaque regulatory mechanism and the operation is not transparent. The principle of fairness is the basic principle of the rule of law society, if the income distribution is unfair, it will create a series of social stability problems, which is harmful to the development of land capitalization.

Land Protection. In the process of capitalization of rural collective land resources, the pollution of land is caused by the defects of the project in ecological protection. In addition, the business category is nonscientific and the method is not perfect, which lead to the failure to achieve the desired results. Still, they may fail to synchronize the realization of social, economic, ecological benefits of the three maximization, and also destroy the livelihood of farmers living home[2]. However, in the process of capitalization of rural collective land, we should pay attention to the rationality of audit operation, that is, whether it is a new type of economic organization that can benefit farmers, protect resources and not cause vicious environmental pollution.

Land Market Regulation. The land capitalization makes the land become "commodity", and the commodity is negotiable. However, the land in the circulation process is influenced by many market factors. Due to the defective market mechanism, it cannot make the capital achieve the benefit maximization, therefore the market risk is high.

\section{The Countermeasures to Improve the Capitalization of Rural Collective Land in Wenjiang District}

Improving Agricultural Productivity. Only by improving the efficiency of agricultural production can we save land for capitalization.And we need land resources, talents, technology and policy support to develop.

Firstly, we should consider the integration of agricultural resources. Under the condition of agricultural production, the agricultural productivity cannot be developed rapidly because of the lack of the financial resources and technical support, as well as the shortage of agricultural knowledge. Expanding the scope of contract can be more conducive to the integration of production resources and the allocation of resources, which also provides more abundant means of production for agricultural mechanization and lay the foundation of production rationalization.

Secondly, strengthening training is important. Because of the weak quality of the agricultural production organization itself, it is difficult to achieve self-educated training. So it needs the support of national capital and talents to meet the demand. To improve the production quality of personnel to a reasonable state can strengthen the proficiency and acceptance of production technology. Farmers can have a better understanding of the land capitalization, greatly improving the farmers' agricultural production enthusiasm.

Thirdly, it is critical to internalize the surplus labor. With the development of agricultural productivity, it will lead to surplus labor.If the surplus labor force is not fully utilized, there will be labor idle, which will greatly hinder the farmer's production enthusiasm. Thereforere need to achieve the effective shift of surplus labor.

Improving the System. The establishment of a sound and supervisory role of the land transfer system is necessary. In terms of its institutional content, there may be some challenged, that is, to make clear provisions on the problems emergingin the capitalization of land, 
including the ages of use, the way of circulation, the way of recovery and the problem-solving, so as to prevent the capitalist form of pursuing the economic benefit alone, regardless of the destruction of other industrial structure, which requires the governmentcontrol from top to bottom[3].

The choice of the form of land capitalization has previously been mentioned to pay attention to economic, social and ecological benefits, before reaching an agreement, what's needed is to make professional judgmentand then select a reasonable and efficient industry. Furthermore, it is also essential to achieve the principle of unity of benefits and to deal with the relationship between agriculture and the common development, such as related industries, which can achieve return to agriculture. Apart from this, a reasonable and effective industry can have a rapid development and will form agglomeration effectincreasing the value of land.

National Macro-Control. The government should set up relevant departments to focus on regulationto regulate the market. This will not only smooth the land capitalization and promote orderly operation, but also canguarantee the interests of farmers. It is important to forecast the land market environment and to study the land market changes to improve the forecasting ability. Then, government should standardize the trading system, establish a set of law of land capitalization and regulate people's behaviors. Lastly, they can make full use of control methods, so that the legal, administrative and market can work together. The market is responsible for the flexibility of land capitalization and profitability, while the legal and administration are in charge of adjusting and punishingthe destruction of market transactions.

\section{Acknowledgements}

This work was financially supported by the Social Practice and Science and Technology Service Group of Postgraduates of Sichuan Agricultural University.

\section{References}

[1] G. Fu, et al.: The Dilemma and Path Choice of Promoting the Marketization of Rural Resources Property Right in China. Agricultural Economic Problems. Forum Vol.11 (2016), p.14-23.

[2] X.Y. Wang: The Legal System of Rural Collective Construction Land Transfer Needs to be Perfected. Rural Economy. Forum Vol.1 (2013), p.21-24.

[3] Z.H. Qian and Y. Mou: The Level of Land Marketization in China: Measure and Analysis. Management World. Forum Vol.7 (2012), p.67-75. 